\title{
Schenute von Atripe: Contra Origenistas
}

Edition des koptischen Textes mit annotierter Übersetzung und Indizes einschließlich einer Übersetzung des 16. Osterfestbriefs des Theophilus in der Fassung des Hieronymus (ep. 96)

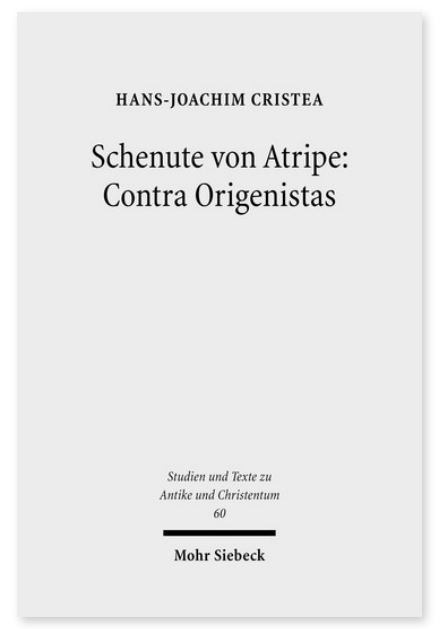

2011. VIII, 387 Seiten. STAC 60

ISBN 978-3-16-151359-6

DOI 10.1628/978-3-16-151359-6

eBook PDF 104,00€

ISBN 978-3-16-150598-0

fadengeheftete Broschur 104,00€
Schenute von Atripe (gest. nach 451), der berühmte Archimandrit und bedeutendste Autor der koptischen Originalliteratur, verteidigt in diesem Traktat die orthodoxe Lehre gegen eine Vielzahl abweichender Strömungen, die von Origenes über Arius und verschiedene gnostische Lehren bis zu seinem Zeitgenossen Nestorius reichen und nach wie vor die monastische Disziplin und Frömmigkeit bedrohen. Nach der Erstedition durch T. Orlandi und der Zuordnung weiterer Textzeugen (sowie der Ermittlung des Incipit: »I Am Amazed«) durch St. Emmel legt Hans-Joachim Cristea hier erstmals eine urkundengetreue Edition aller Handschriften mit deutscher Übersetzung vor. In der Einleitung liegt ein Schwerpunkt auf dem Nachweis der Quellen; die Anmerkungen und die Indizes dienen vor allem der philologischen und linguistischen Erschließung des koptischen Textes. Ein Teil des Werks ist der 16. Osterfestbrief des Theophilus von Alexandria, dessen lateinische Fassung des Hieronymus hier mit der koptischen Version verglichen wird.

Hans-Joachim Cristea Geboren 1962; Studium der Katholischen Theologie, Klassischen Philologie und Wissenschaft vom Christlichen Orient; derzeit Akademischer Rat für Biblische Sprachen an der Theologischen Fakultät Trier.

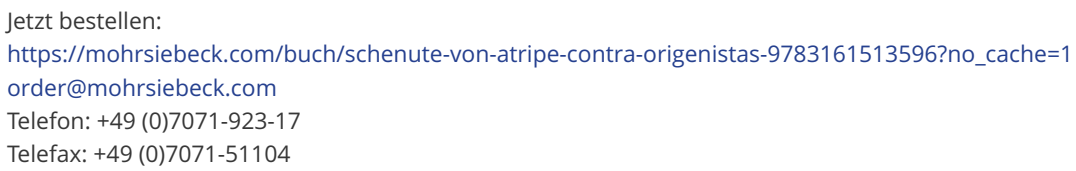

